\title{
The Impact of Mobile Payments on the Success and Growth of Micro-Business: The Case of M-Pesa in Kenya
}

\author{
Marion Mbogo
}

\begin{abstract}
Micro-business enterprises in the developing world are increasingly deploying the use of mobile payments to enhance the quality of their services and increase growth. The pace of transformation in the micro business sector has speeded up with more micro businesses realizing the potential of using the mobile payments in their service delivery. However, there are only a handful of studies on the application of digital technology for success and growth on micro business.

This paper aims to investigate the success factors attributable to the use of mobile payments by micro-business operators. The study is based on a survey conducted through administration of questionnaires. The data was collected from a sample of 409 micro business entrepreneurs in Nairobi, Kenya. The study applies the Theory of Technology Acceptance Model (TAM) which was extended to include other factors to help us predict success and growth in micro-businesses. Analyses of the data reveal that convenience of the money transfer technology plus its accessibility, cost, support and security factors are related to behavioral intention to use and actual usage of the mobile payment services by the micro businesses to enhance their success and growth.
\end{abstract}

Keywords: Mobile payment, M-Pesa, micro business, technology acceptance, business success.

\section{Introduction}

Business practices in Kenya have gone through many changes, the most important being the introduction of Information Communication and Technology (ICT). The mobile phones have been a key ICT product that has affected business practices. This is manifest in various areas including advertisements, marketing, emergence of new products, and new methods of payments. The methods of payment through the use of mobile phones have been the most recent development in Kenya and have revolutionalized how business is conducted among the smallscale business holders. Micro-businesses have embraced the use of mobile payment technology in their operations. They view this mode of payment as an easier form of cash delivery to their suppliers and business partners, a system which is relatively affordable, personal and can be used anywhere and at any time (Anurag, Tyagi and Raddi, 2009). There is appeal and utility of mobile 
banking and mobile payment services across the country as there are probably more people with mobile handsets than with bank accounts (Porteous, 2006).

The majority of the micro businesses in Kenya operate in the informal sector (GOK, 1999) with most of them being sole proprietorships or family businesses usually employing less than five persons. They are involved in small semi-organized and sometimes unregulated activities that are mainly concentrated in urban as well as in some parts of the rural areas. The business functions are usually conducted by the owner/manager in market stalls, open-yards, residential houses and on undeveloped open grounds. Under the Local Government Act CAP 265 of the Laws of Kenya, these businesses are required to be registered and licensed by the municipal, town or county councils of the areas where they operate from but many of them are not registered. Many of these micro business operators do not have bank accounts while those who do, find the bank accounts cumbersome to operate as they have to leave their businesses unattended in order to conduct transactions in a bank.

In March 2007, Safaricom mobile operator launched the mobile money transfer system, the MPesa. Since then the mobile payment system has become popular with both the banked and the unbanked population. Micro-business operators in Kenya have adopted the use of the mobile payments as a way of transacting their business because of the relative affordability of mobile phones and the mobile banking services they offer. Various transactions are carried out using mobile payments such as paying suppliers for goods and services, paying bills, sending money to friends and relatives, withdrawing cash and topping up airtime accounts. Currently some mobile operators offer calling cards of denomination for as low as twenty Kenya shillings which provide affordable reach to most users (CCK, 2008/09). Arunga and Kahora (2007) concluded that sole proprietors and small businesses in Kenya benefited hugely from the mobile phone revolution as they are able to make savings and gain access to more customers and new services.

The micro-business operators are able to transact payments directly with their customers and suppliers through a mobile phone in the palm of their hands without necessarily going through a bank (Anuradi, Tyagi and Raddi, 2009) and without having to leave their business premises. This 
is beneficial because all it requires is for one to have a mobile phone and basic literacy to operate the phone. Other benefits derive from the fact that the system does not rely on any physical infrastructure such as phone wires and is accessible to a large segment of the population (Elder and Rashid, 2009); and from the fast speed in transacting money transfers. These features bring considerable convenience to business operations. The mobile payment providers' agents are well distributed and easily accessible to the micro-business owners for support of their services in Kenya. It is also easy for the micro business operators to control their mobile phone accounts as they can access their accounts any time.

Mobile technology is relatively a new business practice in Kenya as it was introduced about ten years ago. Nonetheless it is being widely used by a large population of the micro-businesses therefore making it thrive in the midst of many banks. This research will be based on the mobile payment technology with a specific emphasis on the Global System for Mobile Communications (GSM) provider, Safaricom mobile payment, M-Pesa. The research will focus on this mobile payment provider because it was the first to be introduced in the country and has more subscribers than any other. The rate of Safaricom's M-Pesa mobile payment usage in Kenya has been steadily increasing since M-Pesa was introduced in March 2007, with five million subscribers as at $31^{\text {st }}$ December, 2008 out of the Safaricom mobile subscriber base of twelve million as at the same date (Business Daily, January 12, 2009). Kenya's population is estimated at 40 million people.

Several mobile payment trend studies have revealed the potential of mobile network technologies for payment purposes (Pousttchi, 2003; Taga and Karlson, 2004; Speedfacts online Research, 2001). Most of these studies were conducted in developed countries and thus may not reflect the impact on the success and growth of different business environments and in particular the micro businesses in a developing country like Kenya. There exists a need therefore, for a substantive research on the impact of mobile payments on the success and growth of micro-business operators who are among those who employ mobile payments in Kenya. So far there has been no clear insight into the role that micro payments play in the development of micro-business. This implies that technology providers, government agencies and development partners may not address the required interventions and there is therefore a need to examine the contribution of 
mobile payment technology on micro businesses and the impact on their success and growth. The micro business operator also needs to fully understand the entrepreneurial impact of this new technology on their business so as to cope with the increasing developments in the mobile payment services on one hand, and the challenges of the micro business operating environment, on the other hand. The choice and use of technology in micro business is dependent on how well it is likely to influence greater success and growth of the business.

This study begins by first looking at the factors that account for the M-Pesa mobile payments fast acceptance among the micro business operators and secondly at the level of actual usage of the mobile payments by the micro business operators. The research applies the Technology Acceptance Model (TAM) to get a better understanding of the micro business entrepreneurs' behavior of using the mobile payment technology to influence the micro business success and growth. The factors that enhance the behavioral intention to use the mobile payment technology and the actual usage of this new technology by micro businesses are highlighted.

\section{Statement of the problem}

Since March 2007 when the mobile money transfer system M-Pesa, was launched by Safaricom mobile operator, the mobile payment has become popular with both the banked and the unbanked population serving as a deposit account for some. The service enables subscribers to use their mobile phones to carry out transactions such as pay for goods and services, pay bills, send to and receive money from friends and family, withdraw cash for their use, top up their own airtime account or top up someone else's account and manage their own accounts

The use of mobile payment technology requires basic knowledge to operate. As a result, majority of the micro business operators in Kenya have embraced its use in their daily business operations and are registered users of M-Pesa. Consequently, they carry out various transactions using their mobile phones within and around their business surroundings such as paying suppliers for goods and services, paying bills, sending money to friends and relatives, withdrawing cash and topping up airtime accounts. They are able to know their account balances and easily manage their accounts. This has enabled the banked to avoid long queues at banks. The banked and the unbanked can also maintain account balances in their mobile phones which can be perceived as 
deposits (Njenga, 2009). This has become a convenient way of doing business. However, there are no existing studies that have been done to find out the impact of using these mobile payments on the success and growth of these micro businesses. This study investigates the factors that enhance the behavioral intention to use the mobile payment technology, M-Pesa and whether the actual usage results in the success and growth of the micro businesses. The study offers insight into the investment in this mobile payment technology by the micro business operators and gives propositions for future research in this area.

\section{Rationale}

It is important to investigate the success factors attributable to the use of mobile payments by micro business operators because this would provide significant insight into the entrepreneurial impact of the mobile payments technology investment to the micro business operators, the mobile payment technology providers, the government and scholars and researchers. The mobile payment technology provider and his agents will offer the necessary technical support and advice to their clients as well as providing new developments. The government will provide the required regulations and other interventions that are necessary to ensure smooth operations for all concerned parties. Scholars and researchers may wish to use the findings and carry out further research.

\section{Theoretical Background and Research Hypothesis}

Mobile payment procedures are essentially information technology (IT) procedures and channels through which users make various payment transactions. Studies show that the acceptance to use the mobile payments varies with the context in which users are able to use a mobile payment procedure. Moreover, the mobile payment procedures are functional services adopted for utilitarian reasons (Khodawandi, Pousttchi and Wiedmann, 2003). This study focuses on the factors influencing the mobile payments usage by the micro business operators and applies the Theory of Technology Acceptance Model (TAM). TAM is a theoretical model that explains how users come to accept and use a technology (Davis, 1989). The model suggests that when users are presented with a new technology, a number of factors influence their decision about how and when they will use it. These factors are perceived usefulness defined as the degree to which a person believes that using a particular system would enhance his or her job performance, 
and perceived ease of use defined as the degree to which a person believes that using a particular system would be free from effort (Davis, 1989). These two factors are considered to be the primary determinants for adopting and using a new technology and are influenced by other variables such as security concerns, cost, convenience, and satisfaction (Lu, Yu, Liu and Yao, 2003). Perceived ease of use directly affects perceived usefulness and both determine the user's attitude towards use, (behavioral intention to use -BIU) and eventually to the actual use of the system (Viehland and Leong, 2007).

TAM has been widely used to predict user acceptance and use based on perceived usefulness and ease of use (Ndubisi and Richardson, 2002). Consequently, TAM was chosen as the appropriate model and was extended to include other factors such as perceived ease of accessibility of the mobile payment services, perceived low cost of the mobile payment services, perceived convenience, perceived security, perceived support from the mobile services provider and from the government, perceived satisfaction and actual usage of the mobile payments. Figure 1 presents the research framework examined in this study and integrates the theoretical perspectives of previous studies discussed above.

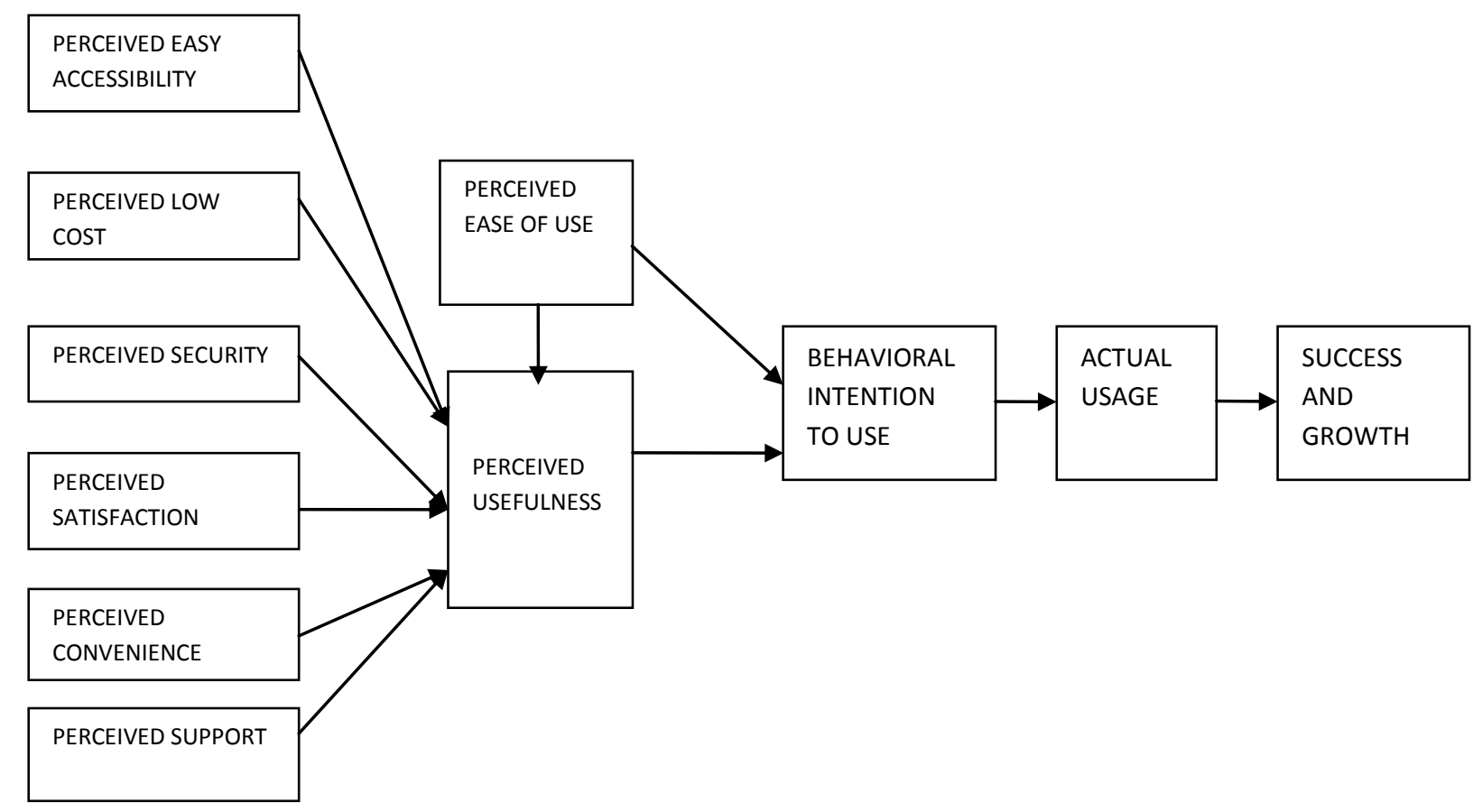

Figure 1: Adapted TAM Model of Adoption of Mobile Payment Services 


\subsection{Easy accessibility}

Pagani (2004), states that accessibility (ability to reach the required services) is one of the main advantages of mobile payment services. Small and micro businesses are among the greatest beneficiaries of using M-Pesa mobile payment. As at $31^{\text {st }}$ March, 2009, there were 8,650 MPesa agents spread throughout the country offering the mobile payments service ( Annual report, 2008/2009). The micro-business operators go to the bank less often and spend more time running their businesses. Equally, many unbanked Kenyans can now receive or send money wherever they are in the country (Omwansa, 2009). Majority of the micro business operators are familiar with the use of the mobile payment services as they are easy to use and require no formal training before use. The following hypothesis was formulated to test this variable.

H1 Easy accessibility positively influences the success and growth of the micro business.

\subsection{Transaction Costs}

The transaction costs of sending money through the mobile payment technology are lower than those of banks and money transfer companies (Omwansa, 2009). The cost of a payment transaction has a direct effect on consumer adoption if the cost is passed on to customers (Mallat 2007). Transaction costs should be low to make the total cost of the transaction competitive. The cost of the mobile payments should be affordable to most of the micro business operators and far below what the banks normally charge for their bank transactions. There are many different mobile handsets which are easy to operate and have the functionalities required for the mobile payment technology. For this variable, the following hypothesis was formulated.

\section{H2 Cost positively influences the success and growth of micro business.}

\subsection{Convenience and Security}

Njenga (2009) states that although the mobile phone balances may seem low, the fact that there are balances proves that there is storage which can be perceived as acceptance of deposits. This is a significant indication of the high value placed on the convenience associated with the use of the mobile payment services. Omwansa (2009) states that a lost or stolen mobile phone does not mean catastrophe as no one can access an M-Pesa account without a correct personal identification number 
(PIN). He further explains that in a country where majority of people have no bank accounts, M-Pesa provides both convenience and safety. People walk around with their virtual money knowing they can withdraw cash any time at a minimal fee. In a mobile environment, it is necessary to have perceived security and trust in the vendors and the payment system. (Siau, et al., 2004; Mallat, 2007). Security and safety of mobile payment transactions is one of the primary concerns for users (Nam, Yi, Lee and Lim, 2005). They state that safety represents no delay, no transaction incompleteness and no private information disclosure during payment transactions. The use of the pin and secret code for the M-Pesa transactions enhances the security and privacy issues. Key requirements for any financial transaction in an electronic environment should include confidentiality, authentication, data integrity and non-repudiation (Shon \& Swatman, 1998). Other security factors important to the users are anonymity and privacy, which relate to use policies of customers' personal information (Jayawardhena \& Foley, 1998; Shon \& Swatman, 1998; Mallat, 2007). The hypotheses for these variables were formulated as follows:

\section{H3 Convenience positively influences the success and growth of micro business.}

H4 Security positively influences the success and growth of micro business.

\subsection{Perceived Support from the Mobile Payments Provider}

Payment systems exhibit network externalities as the value of a payment system to a single user increases when more users begin to use it (Van Hove, 2001, Mallat, 2007). Consumer decision to adopt a payment system is therefore significantly affected by the amount of other consumers and traders using it. Failure to create a critical mass has contributed to discontinuance of several previous payment systems, including several smart card systems (Szmigin \& Bourne, 1999). It is therefore a critical success factor for the M-Pesa mobile payment provider to reach a wide enough base. The coverage area of the M-Pesa mobile payments is spread throughout the country with over six million registered subscriber base as at $31^{\text {st }}$ March, 2009 (Annual Report 2008/2009). The following hypotheses for this factor were therefore constructed:

H5 Support from the mobile payment services provider positively influences the success and growth of micro business. 


\subsection{Satisfaction}

Personal experiences for a lot of people indicate that the current technology is user friendly and previous studies of the adoption of mobile payments show that it is the usability, usefulness, speed and convenience of the service itself that counts (Pagani, 2004). Safaricom's Annual Report for Year 2008/2009 shows that by end of March 2009, there were over 6.175 million registered M-Pesa customers with an average of 11,580 new registrations per day representing a growth of $198 \%$ from the previous year (Annual Report 2008/2009). This indicates the wide usage and satisfaction that the existing customers have reported which in turn has influenced new customers to take up the services. The hypothesis for this variable is thus formulated:

H6 Satisfaction of the mobile payment services positively influences the success and growth of micro business.

\subsection{Actual Usage of the Mobile Payment and business performance}

The rapid spread of the mobile phone usage in Kenya means that the number of mobile users exceeds by far the number of banked people. Mobile phones offer easy communication and the current MPesa facilities have reduced the average transaction costs for the consumer (Vaughn, 2009). The Annual Report 2008/2009 show that person to person transactions stood at KShs. 120.61 billion for the same year against 14.74 billion for the year 2007/2008. The total cumulative person to person transactions stood at KShs. 135.38 billion as at $31^{\text {st }}$ March 2009 since inception of the mobile payment service. This indicates that M-Pesa mobile payment is reaching the unbanked (Vaughn, 2009). Omwansa (2009) argues that the benefits associated with M-Pesa are so enormous that those who try to place regulatory pressure on it might feel guilty if they appear to frustrate it.

The extent to which the mobile payment usage would impact on performance depends largely on whether there is an enabling environment (Porteous, 2006). Porteous defines an enabling environment as a set of conditions which promote a sustainable trajectory of market development. Of particular interest are the environments in which widespread access is likely. M-Pesa has widespread access and requires an enabling environment to enhance the success of its consumers. The micro businesses are spread throughout the country with huge clusters in the market areas and near shopping centers. This enables them to easily access the M-Pesa service providers for registration and to make cash deposits into their accounts. The mobile payment providers' agents 
are well distributed and easily accessible to the micro business owners for support of their services in Kenya. The following hypotheses were formulated for this variable:

\section{H7 Intention to use impacts on actual usage of the mobile payment services}

H8 Actual usage of the mobile payments positively impacts on the success and growth of the micro business

Table 1 below shows the changes that have occurred in the M-Pesa mobile payment for the year 2008/2009

Table 1 Trend of Mobile Payment Service M-Pesa

\begin{tabular}{|l|l|l|l|}
\hline & $\begin{array}{l}\mathbf{2 0 0 8} \\
\text { March }\end{array}$ & $\begin{array}{l}\mathbf{2 0 0 9} \\
\text { March }\end{array}$ & $\begin{array}{l}\text { Growth rate of the } \\
\text { mobile payment service }\end{array}$ \\
\hline $\begin{array}{l}\text { Number of registered } \\
\text { customers }\end{array}$ & 2.075 million & 6.175 million & $198 \%$ \\
\hline Number of retail outlets & 2,262 & 8,650 & $282 \%$ \\
\hline $\begin{array}{l}\text { Number of person to } \\
\text { person transactions }\end{array}$ & 14.74 billion & 120.61 billion & $718 \%$ \\
\hline $\begin{array}{l}\text { Average registrations } \\
\text { per day }\end{array}$ & 9,965 & 11,580 & $19 \%$ \\
\hline
\end{tabular}

\section{Source: Safaricom Annual Report, 2008/2009}

\section{Research Methodology}

A survey based on clusters was conducted within Nairobi Central Business District and the residential areas within the eight constituencies of Nairobi to collect data. The survey method is appropriate for this kind of study as it provides a quantitative description of attitudes, experience and opinions of the sample population (Creswell, 2003; Viehland \& Leong, 2007). A research questionnaire was distributed to a selected sample of the micro business operators within the eight constituencies including the Nairobi Central Business District. The questionnaire included the construct items adapted from previous studies (Davis, 1989; Venkatesh and Bala, 2008) and some questions on demographics. The respondents were required to complete the questionnaire voluntarily. A total of 409 micro business operators completed the questionnaires out of 450 
distributed questionnaires. The completed questionnaires were checked for plausibility, integrity and completeness resulting in 381 usable cases.

All the items used to measure the constructs were adapted from previous research but modified to fit the specific context of this study. Eight independent variables with various factors were identified and measured using a five-point scale with polar anchors ranging from 1 (strongly disagree) to 5 (strongly agree). These were perceived ease of accessibility, low cost, security, satisfaction, convenience, support, behavioral intention to use and actual usage. The respondents' demographic information such as gender, age group, years in business and period of use of the mobile payment service was also captured using single item questions.

To discover the factors that influence the intention to use the mobile payment services by the micro-businesses, factor analysis were employed. Principal component analysis with varimax rotation was used to sort out significant factors among the variables. The number of factors was determined based on the number of principal components in which the Eigen value was greater than one. To get a more interpretable factor structure, a varimax rotation was carried out.

\section{Data Analysis}

Four hundred and nine responses were completed by the participating micro-business operators representing a response rate of ninety one percent. Three hundred and eighty one cases were usable for further analyses. There were more male than female respondents $(54 \%, 46 \%)$. Over $85 \%$ of the sample respondents are between eighteen and thirty five years old. Forty one percent have been in business for less than five years while $19 \%$ have been in business for over ten years. Forty nine percent have used the mobile payment services for less than one year while $40 \%$ have used the services for between 1 and 2 years. Table 2 summarizes the demographic profile of the respondents. 
Table 2 Demographic Characteristics of the Sample $(\mathbf{N}=381)$

\begin{tabular}{|c|c|c|}
\hline Item & N & $\%$ \\
\hline Gender & & \\
\hline Male & 206 & $54 \%$ \\
\hline Female & 175 & $46 \%$ \\
\hline Age Group & & \\
\hline $18-24$ & 107 & $28 \%$ \\
\hline $25-30$ & 137 & $36 \%$ \\
\hline $31-35$ & 80 & $21 \%$ \\
\hline $36-40$ & 27 & $7 \%$ \\
\hline Over 40 & 30 & $8 \%$ \\
\hline Less than 5 years & & \\
\hline 5-10 Years & 157 & $41 \%$ \\
\hline 11-20 Years & 152 & $40 \%$ \\
\hline Over 20 Years & 42 & $11 \%$ \\
\hline Less than 1 Year & 30 & $8 \%$ \\
\hline 1-2 Years & & \\
\hline Slightly over 2 Years & 187 & $49 \%$ \\
\hline & 152 & $40 \%$ \\
\hline
\end{tabular}

Table 3 shows the results of descriptive statistics. A higher mean value generally means that there is a higher level of measured construct. This study is exploratory in nature and therefore the collected data are further analyzed using Pearson's Correlation coefficient to measure how variables are related.

Table 3 Descriptive Statistics

\begin{tabular}{|l|l|l|l|l|l|}
\hline & $\mathrm{N}$ & Minimum & Maximum & Mean & Std. Deviation \\
\hline PERCEIVED ACCESSIBILITY & 381 & 1 & 5 & 4.20 & .887 \\
\hline PERCEIVED LOW COST & 381 & 1 & 5 & 4.03 & 1.032 \\
\hline PERCEIVED SECURITY & 381 & 1 & 5 & 3.91 & 1.042 \\
\hline PERCEIVED SATISFACTION & 381 & 1 & 5 & 3.90 & 1.012 \\
\hline PERCEIVED CONVENIENCE & 381 & 1 & 5 & 4.05 & .964 \\
\hline PERCEIVED SUPPORT & 381 & 1 & 5 & 3.91 & 1.051 \\
\hline $\begin{array}{l}\text { BEHAVIOURAL INTENTION } \\
\text { TO USE }\end{array}$ & 381 & 1 & 5 & 4.14 & .943 \\
\hline ACTUAL USAGE & 381 & 1 & 5 & 2.67 & 1.401 \\
\hline
\end{tabular}

Cronbach's alpha shown in Table 4 was used to assess the internal consistency reliability for each of the eight variables. All the constructs in the survey questionnaire were factor analyzed to 
validate their reliability. Higher scores indicate more reliability for the measurements. Nunnally (1978) has indicated 0.7 to be an acceptable reliability coefficient but lower thresholds are sometimes used. It should be noted that the reliability of perceived support, perceived cost and perceived security are relatively weak. Since these constructs are proposed for the current study, further analysis in future research could be addressed.

Table 4: Measurements Reliability Statistics for Each Construct

\begin{tabular}{|l|l|l|}
\hline Construct & Number of Items & Cronbach's Alpha $\alpha$ \\
\hline Perceived Accessibility (PAccess) & 5 & .676 \\
\hline Perceived Low Cost (PCost) & 3 & .559 \\
\hline Perceived Security (PSecurity) & 3 & .575 \\
\hline Perceived Support (PSupport) & 3 & .523 \\
\hline Perceived Satisfaction (PSatisfaction) & 3 & .704 \\
\hline Perceived Convenience (PConvenience) & 5 & .779 \\
\hline Behavioral intention to use(BIU) & 2 & .854 \\
\hline Actual usage & 6 & .869 \\
\hline
\end{tabular}

Table 5 presents the Bivariate Correlation test showing the degree of correlation among the variables. Pearson's correlation coefficient gives information about the degree of correlation as well as the direction of the correlation. Some variables indicate a moderate degree of correlation among them with correlations lying between 0.25 and 0.75 while some have a low correlation. No variables show a high degree of correlation. 
Table 5: Pearson Correlation

\begin{tabular}{|c|c|c|c|c|c|c|c|c|}
\hline & PACCESS & PCOST & PSECURITY & $\begin{array}{l}\text { ACTUA } \\
\text { LUSAGE }\end{array}$ & $\begin{array}{l}\text { PSATIS } \\
\text { FACTI } \\
\text { ON } \\
\end{array}$ & $\begin{array}{l}\text { PCONVE } \\
\text { NIENCE }\end{array}$ & PSUPPORT & $\mathrm{BIU}$ \\
\hline PACCESS & 1 & & & & & & & \\
\hline PCOST & $.562(* *)$ & 1 & & & & & & \\
\hline PSECURITY & $.562(* *)$ & $1.000(* *)$ & 1 & & & & & \\
\hline ACTUALUSAGE & $.265(* *)$ & $.240(* *)$ & $.240(* *)$ & 1 & & & & \\
\hline PSATISFACTION & $.491(* *)$ & $.458(* *)$ & $.458(* *)$ & $.221(* *)$ & 1 & & & \\
\hline PCONVENIENCE & $.541(* *)$ & $.379(* *)$ & $.379(* *)$ & $.322(* *)$ & $.595(* *)$ & 1 & & \\
\hline PSUPPORT & $.330(* *)$ & $.321(* *)$ & $.321(* *)$ & $.170(* *)$ & $.339(* *)$ & $.430(* *)$ & 1 & \\
\hline BIU & $.398(* *)$ & $.303(* *)$ & $.303(* *)$ & $.208(* *)$ & $.463(* *)$ & $.657(* *)$ & $.528(* *)$ & 1 \\
\hline
\end{tabular}

** Correlation is significant at the 0.01 level (2-tailed).

* Correlation is significant at the 0.05 level (2-tailed).

\section{Factor Analysis}

As a result of using principal component analysis with a varimax rotation, the number of factors is determined by the criteria that the eigen value is greater than one and the communality of each variable is greater than 0.55 (Hair, et al, 1998). Table 6 summarizes the results of factor analysis with seven factors being identified from the original variables. These are convenience of the mobile payments, personal use, support from the service provider, perception of cost, perception of safety, propensity to use mobile payments and expected support from the government. All the seven factors have Eigen values of greater than 1 and the total variance explained by the seven factors extracted from factor analysis is $60.86 \%$ and the Kaiser-Meyer-Olkin Measure of Sampling Adequacy value that indicates the appropriateness of factor analysis is 0.883 . 
Table 6: Results of Factor Analysis

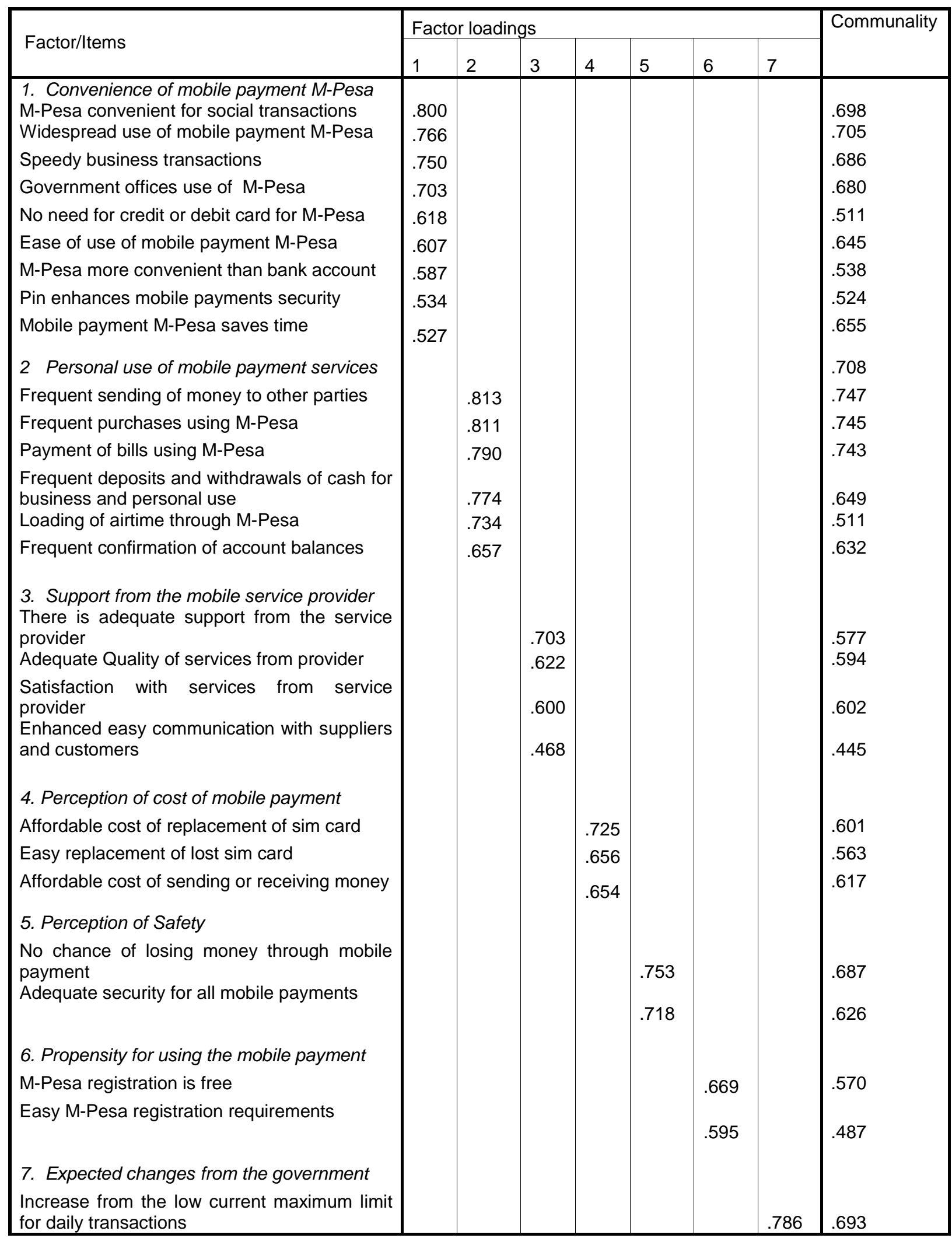




\section{Discussion of the Results}

The primary objective of this study was to examine the extent to which the use of mobile payment services has influenced the success and growth of micro business in Kenya in the light of technology acceptance model (TAM). The research used existing variables from research conducted by other scholars and other variables that are relevant to the use of mobile payments. From figure 1 and Table 5 show that perceived accessibility, low cost, security, convenience, satisfaction and support factors are all positively correlated with the behavioral intention to use the mobile payment. In addition, behavioral intention to use is significantly correlated with actual usage. Behavioral intention to use the mobile payment has a moderately high correlation of .657 with perceived convenience. Further there is evidence in this research that all the constructs had a significant impact on the intention to use the mobile payment services. This implies that those micro business operators who use the mobile payment also acknowledge the existence of all the perceived constructs in the study and positively identify with the mobile payment usage.

There is however, a low degree of correlation between perceived support and actual usage at 0.170. This implies that the micro business users of the mobile payment expect more support from both the mobile payment service provider and from the government such as increased minimum daily transaction amounts and reduction in congestion of the service lines. Actual usage of the mobile payment is however, significantly correlated with all the other constructs suggesting that the micro business operators perceive that the use of the mobile payment services is advantageous to them with regard to its convenience, support, cost, satisfaction and safety. They acknowledge continuous use of the mobile payment with adequate support from both government and service provider will positively impact their businesses.

\section{Research Limitations}

Although the results can be considered statistically significant in most parts, the study has several limitations. Firstly, the study was based on micro businesses within the central business district and its environs in Nairobi, Kenya. It would be interesting to see how the results would be if the sample included other urban as well as the rural micro businesses in the country. Thus future replication of the study incorporating other areas would be eligible. 
Secondly, the study did not differentiate between the formal and informal micro businesses. A further study is recommended in this area.

Thirdly, micro businesses operate in all forms of activities. This study did not differentiate the various activities and the results should be treated with caution. This provides an avenue for further research.

Fourthly, no studies in the past have considered the success and growth factor in the micro business as a result of using the mobile payment. Further research covering a wider scope of the micro businesses to refine these results is needed.

Finally, the study did not look at gender in micro-business vis-à-vis the use of mobile payments. Further study in this area remains an avenue to be explored in the future.

\section{Conclusion and Implications}

The results contribute to the existing literature in several ways. First, is in relation to factors that cause micro businesses to adopt mobile payment services as shown using factor analysis. The results show that perceived convenience had influence on the intention to use the mobile payment services. Secondly, perceived support from the mobile payment services provider influences the intention to use. Thirdly, perceived support from the mobile services provider had an impact on the perceived convenience. From a practical point of view, this would be consistent because the services become convenient to the user if they are adequately supported by the provider. Previous studies have explored convenience as one of the factors that contributes to the use of mobile payments (Pousttchi, 2003). Fourthly, perceived ease of accessibility had an impact on the intention to use the mobile payment services. Majority of the micro business operators who completed the survey questionnaire strongly agree that accessibility of the mobile phone payment is easy.

Mobile payment technology is increasingly being used by micro business enterprises in Kenya. These findings provide evidence to support that the mobile payments users consider the technology to be convenient, well supported and that perceived advantages will influence the behavior to use the technology. This supports previous studies. The findings of this research are useful to the mobile payments providers who may use them to provide greater support and enhance customers' convenience to use the technology. 
Based on the research model and research findings, the government and the mobile service providers can enhance the micro business operators' use of the mobile payments and the digital technology by:

1) Increasing the daily transaction amounts from the existing low minimum of Kshs.35,000. This will enable the businessmen to transact larger payments.

2) Provide infrastructure that minimizes congestion periods within the mobile network.

3) Enhance security measures.

The above measures would encourage positive attitude in the mobile payment users which would result in increased use of the services.

This exploratory study has identified some important factors that are attributable to the success of micro business operators using mobile payment services. More and more people are increasingly using the mobile payment services and a more extensive research should be conducted to bring out those factors that are necessary to ensure that the micro businesses embrace the digital technology in the conduct of their business and enhance their business performance.

\section{References}

Agarwal, R. and Karahanna, E. (2000). "Time Flies when you're having fun: Cognitive absorption and beliefs about information technology usage". MIS Quarterly, , 24(4): 665-69.

Ajzen, I, and Fishbein, M. "Understanding attitudes and Predicting Social Behavior". Englewood Cliffs, NJ, USA: Prentice Hall.1980.

Anurag, S, Tyagi, R, and Raddi S (2009). "Mobile Payment 2.0: The Next-Generation Model," in HSBC"s Guide to cash, Supply Chain and Treasury Management in Asia Pacific.Ed.178-183. Arunga J, Kahora B (2007). Cell phone Revolution in Kenya. International Policy Network.

Business Daily, April 18, 2009. "Minister orders audit of Safaricom M-Pesa service". http://www.bdafrica.com Accessed on $18^{\text {th }}$ April, 2009

Business Daily. "M-pesa success stirs bank fury as 5 million subscribers enroll” Business Daily. January 12, 2009. <http://www.bdafrica.com> accessed on $18^{\text {th }}$ April, 2009

Business. "Price Wars Loom as Zain Launches Cheaper Money Transfer Service", The East African. February 21, 2009. <http://www.theeastafrican.co.ke. Accessed on $18^{\text {th }}$ April, 2009 
Carneghie Council Publications. "Turning Cellphones into 24-Hour Tellers in Kenya. Policy Innovations".

Communications Commission of Kenya, (2008/09). Communications Statistics Report Second Quarter. <http: //www.cck.go.ke.> Accessed on $28^{\text {th }}$ April, 2009.

Creswell, J. W. (2003). Research Design: Qualitative, Quantitative, and Mixed method Approaches, $2^{\text {nd }}$ ed. Sage Publication, Thousand Oaks, California.

Crump, B. J., Logan, K. A. and Mcllroy, A. (2007). Does Gender Still Matter? A study of the views of women in the ICT Industry in New Zealand. Gender, Work and Organization, 14 (4)249-370.

Davis, F D (1989) "Perceived Usefulness, Perceived Ease of Use and User Acceptance of Information Technology". MIS Quarterly 13 (3), 319-339.

Deci E L. Intrinsic Motivation. New York: Plenum, USA, 1975. Deloitte's Touché Tohmatsu (2008). "Small Device, Big Business?" Paper presented at the IV Hungarian Mobile Conference, Budapest. $\leq$ http://www.deloitte.com> Accessed on $28^{\text {th }}$ April, 2009.

Doll, W. J., Hendrickson, A. and Deng, X. (1998). "Using Davis's Perceived Usefulness and Ease-of-use Instruments For Decision Making: A confirmatory and multigroup invariance analysis". Decision Sciences 29, 839-869.

Eagle, N (2005). Entrepreneurship and Education Through Mobile phones in Kenya. The MIT Media laboratory, Human Dynamics group.

Elder, L. and Rashid, A.T. (2009) "Mobile Phones and Development: An analysis of IDRCSupported Projects". The Electronic Journal on Information Systems in Developing Countries 36, 2, 〈http://www.ejisdc.org. $>$ Accessed on $28^{\text {th }}$ April, 2009.

Gefen, D. and Straub, T. (2000). "The Relative Importance Of Perceived Ease-of-use In IS Adoption: A study of e-commerce adoption". Journal of the Association for Information Systems 1(8), 1-30.

Government of Kenya, (1999) National Medium and Small Enterprises Baseline Survey, Kenya National Bureau of Statistics. $\quad$ http://www.knbs.go.ke. $>$ Accessed $28^{\text {th }}$ April, 2009. Government of Kenya, (1999) Labor Force Survey, Kenya National Bureau of Statistics.

〈http://www.knbs.go.ke.> Accessed $28^{\text {th }}$ April, 2009. 
Government of Kenya, (2008). Kenya National Bureau of Statistics. http://www.knbs.go.ke. Accessed $28^{\text {th }}$ April, 2009.

Hair, J. F., Anderson, R. E., Black, W.C., Tatham, R. L.(1998), Multivariate data analysis, $5^{\text {th }}$ Edition, Prentice Hall, Engelwood Cliffs,

New Jersey, U.S.A.

Hashim J. (2008).Learning Barriers In Adopting ICT Among Selected Working Women In Malaysia. Gender in Management: An International Journal 23(5), 317-336

Hermes Newsletter (2001) "Mobile Commerce and its Future. "Electronic Retailing and emarketing". 11. Edited by MobiCom Team. http://www.eltrun.aueb.gr.

Accessed $28^{\text {th }}$ April, 2009.

Hu, W. C.; Lee, C. W. and Kou, W (2004). "Advances in Security and Payment Methods for Mobile Commerce”. Idea Group Publishing.

Hughes, N. and Lonie S. (2007). M-PESA: Mobile Money for the "Unbanked".

Jackson, C M., Chow, S., Leitch, and R. A. (1997). "Toward An Understanding of the Behavioral Intention to Use an Information System”. Decision Sciences 23, 587-605.

Khodawandi, D., Pousttchi, K. and Turowski, K (2003). Acceptance of Mobile Payment

Procedures In Germany. Proceedings of the $3^{\text {rd }}$ International Workshop Mobile Commerce, Augsburg, Germany.

Kreyer, N., Pousttchi, K., and Turowski, K. (2002). "Standardised Payment Procedures as Key Enabling Factor for Mobile Commerce". Proceedings of the $3^{\text {rd }}$ International Conference on Electronic Commerce and Web Technologies, 400 -409.

Lawson, R., Alcock, C., Cooper, J. and Burgess L. (2003), "Factors Affecting Adoption of Electronic Technologies by SMES: an Australian study", Journal of small business and Enterprise Development, 10 (3), 265-276.

Lynn, M., and Halstead, A. (2003). Knowledge and Vearning In Female Team Managed Firms Adopting Information Communication Technologies (ICTs). Women in Management Review, 13 (6), 334-337.

Mallat, N. (2007). "Exploring Consumer adoption of Mobile Payments- A Qualitative Study". The Journal of Strategic Information Systems, 16 (4), 413-432. 
Ndubisi, N. O. (2007). Evaluating the Direct And Indirect Impact of Traits And Perceptions On technology Adoption By Women Entrepreneurs In Malaysia. Academy of Entrepreneurship Journal, 13 (2), 1-20.

Ndubisi, N. O., Richardson, S. (2002). "The Entrepreneurs' Technology Acceptance Model”. Academy of Entrepreneurship Journal.

Nunnally, J.C. (1978). Psychometric theory ( $2^{\text {nd }}$ Edition). New York: McGraw-Hill.

Njenga, A. D. K.(2009). Mobile phone banking: Usage experiences in Kenya. < http://www.strathmore.edu/pdf/ictc-08/mobile-banking.pdf $>$ Accessed on 30 ${ }^{\text {th }}$ August, 2009.

Pagani, M (2004). "Determinants of Adoption of Third generation Mobile Multimedia services", Journal of Interactive Marketing, 18 (2).

Pavlou, P A. (2003). "Consumer acceptance of electronic commerce: Integrating trust and risk with the technology acceptance model". International Journal of Electronic Commerce 7(3), 69103.

Porteous, D. (2006). The enabling environment for mobile banking in Africa. London: DFID.

Pousttchi, K. (2003). "Conditions for acceptance and usage of mobile payment procedures". MPRA Paper 2912.

Pousttchi, K., Wiedemann, $D G$ (2007). "What Influences Consumers' Intention to Use Mobile Payments?" Proceedings of the 2007 LA Global Mobility Roundtable. Los Angeles, California, USA.

Speedfacts Online Research GmbH (2001). MBanking - the future of Personal Financial Transactions? Franfurt, Germany.

Rogers, E M (1995). Diffusion of Innovations. New York: Free Press.

Roy, S. and Ghose, S.(2006). Converting internet non-users to internet users and to online buyers. University of New Haven: University of Wisconsin, Milwaukee.

Safaricom, (May, 2009), Financial Year 2008/2009; Annual Results Presentation and Investor update.

Sekino, H., Kwon, J. and Bong S H., (2007). "Mobile Payments: Mobile operator Market Opportunities and Business Models", Diamond Management and Technology Consultants Inc. <http://www.diamondconsultants.com $>$ Accessed $28^{\text {th }}$ April, 2009. 
Siau, K, Sheng, H., Nah, F. and Davis, S. (2004). "A qualitative investigation on consumer trust in mobile commerce". International Journal of Electronic Business, 2(3), 283-300.

Taga, K. and Karlsson, J. (2004). Arthur D. little Globa l M-Payment Report, Vienna, Austria.

Omwansa, T. (2009). "M-Pesa progress and prospects": Innovations case discussion. $<$ http://www.strathmore.edu/pdf/innov-gsma-omwansa.pdf. $>$ Accessed $28^{\text {th }}$ April, 2009.

Venkatesh, V, and Davis, F. D. (2000). "Why don't men stop to ask directions? Gender, social influence, and their role in technology acceptance and usage behavior". MIS Quarterly 24. 186204.

Viehland, D and Leong, R S Y (2007). "Acceptance and Use of Mobile Payments". Proceedings of the $18^{\text {th }}$ Australasian Conference on Information Systems. Toowoomba. 